\title{
Self Confidence Enhancement Through Group Guidance Service
}

\author{
Yulianton Ashzar Ibrahim* \\ Postgraduate Guidance and Counseling Program \\ Universitas Negeri Yogyakarta \\ Yogyakarta, Indonesia \\ yuliantonashzar.2018@student.uny.ac.id*
}

\author{
Muh Farozin \\ Department of Educational Psychology and Guidance \\ Universitas Negeri Yogyakarta \\ Yogyakarta, Indonesia \\ farozin@uny.ac.id
}

\begin{abstract}
This study is aimed to improve the self confidence of students through group guidance service. Guidance activities within the group which is a guidance and counseling services in schools are considered able to help the problems experienced by students, the problem of this study is low self confidence. This research is a kind of research experiments that use one group pretest-posttest design. The research subjects were seven students, obtained through purposive sampling techniques that can be obtained using a scale of self confidence. Based on the results of the analysis can be concluded that confidence can be enhanced using group guidance service.
\end{abstract}

Keywords-self confidence, group guidance, guidance and counseling

\section{INTRODUCTION}

Education aims to help students develop their potentials. Students are required to be able to adjust to the environment so that they can develop their quality become an independent person, confident and responsible. Accordingly, education as a process of personal formation is defined as a systematic activity directed at the formation of the personality of students. The process of personal formation that can be through communication and interaction with their environment.

Individual belief about himself appear because people who has good self confidence. Someone who has the confidence to do anything with his confidence will success, if it has fail, one does not necessarily desperate but still have the spirit to try again [1].

A feeling of lack of confidence sometimes come up and suddenly when someone does something so that the person is unable to show or express his true abilities optimally. The description of individuals who have lack confidence include pessimism, hestitation and fear to express their ideas, uncertain to make choices and too much compare themselves with others. Based on that students who have low confidence if left unchecked will hinder their actualization to face life, especially in carrying out development tasks and other more complex problems [2].

Trust in yourself indispensable individuals in order to pass the challenge, dare to take risks, not afraid to fail, dare to argue, realistic and respect for others. Self-confidence is an important part of the development of one's personality as a determinant of how to act and behave. A stance that would encourage an individual to approach the goals and success will be achieved, there is no one who has never experienced a failure but an individual who has the confidence to be able to cope with such failures by attempting to try again, do not despair and keep the spirit [3].

Students consider school as an institution that will realize their future goals. The school was established to help families direct to growth and development of children become completely students. In the implementation of education in school, there are still many students who have various kinds of resistance in learning. Toward resolve any trouble or resistance in learning, students often need guidance from others. Accordingly, one resistance that is often faced by students are lack of self confidence.

Phenomena that exist in school, there are not all students have sufficient good self confidence. The problem of students are self confidence can pose a huge resistance in the field of private life, social, learning and career. Low self confidence contributed to the feeling of inferiority, shame, shy, and an obstacle to students through the process of learning in school and the environment [4].

Confidence adolescence is an important thing, because at that time the student should have is not easily affected, certain of his opinion, does not depend on others, it will be all action, convinced every decision and confident in his ability. Self-confidence is the main potential source of a person in his life. If someone is no longer confident, for example does not believe in his life ideals and the decisions he made and does not believe in the potential and all the possibilities of himself, then all sources of their potential are lost [5].

Based on the existing problems of students who have low self-confidence necessary efforts to build confidence students. How to build confidence in students can be done by organizing activities of group guidance service. Guidance help individuals to achieve their optimal self-development as social beings, while understanding the group is two or more individuals who interact face to face, each aware of his membership in the group, know for certain other individuals who are members of the group, and each each aware of their interdependence positive in achieving a common goal [6]

Group guidance service is expected to be excellent for other services because it emphasizes aspects of group 
dynamics that have high spirits, smooth and steady cooperation, and mutual trust among members. If members feel that the group is good and then each group member will very easily comply with existing rules and norms.

Group guidance service focuses on awareness thinking, behave, oriented towards comfort, trust each other, and mutual benefit. Group guidance is one form of guidance and counseling services to be provided to students who have low confidence in their environment. Students who participated in the guidance and direct practice group can create a dynamic group, that is to practice speaking, express opinions, respond, listen and learn to accept the opinion of one member of the group with other members of the group [7].

Such circumstances if it can be done it will help students to train themselves to develop themselves in understanding themselves, understand others and the environment so that the student's self-confidence can be increased. Provision of group guidance service approach also been the reason see these students enter the adolescent stage at the age of students tend to have a strong need to hang out with a group / peer [8].

Group guidance service activities will utilize group processes such as communication and self-development interactions. Group members will use the group process to train themselves in expressing opinions, discuss problems experienced thoroughly, students can exchange information, provide criticism and suggestions and group members can solve a problem together, can share experiences and discussions so that guidance activities groups support students' personal development that leads to increased selfconfidence.Adolescence, relationships with peers have a greater proportion of the individual's life [8].

Based on the above by following group guidance service, students who have lack self confidence will get a conducive and natural environment in accordance with the development phase and the opportunity to practice expressing ideas, opinions, ideas, and gaining new insights that can shape confident behavior. Toward the purpose of this study was to determine whether or not there was an increase in adolescent self-confidence after attending group guidance explanation can be concluded that students self confidence can be enhanced by using group guidance service.

\section{METHODS}

This study uses a quantitative approach one-group pretest-posttest design that is an experiment carried out on a group without a comparison group [9]. Data analysis is one of the most important steps in research activities. Through data analysis techniques, it can prove the hypothesis. Experimental research aims to determine the impact of a treatment, that is try something new then look at the effects of the treatment [10].

Psychological scale is a measure of aspects or affective attributes. Psychological scale has characteristics such as: stimulus in the form of questions or statements that do not directly reveal the attributes to be measured but rather reveal behavioral indicators of the attributes concerned, because psychological attributes are revealed indirectly through behavioral indicators while behavioral indicators are translated in the form of items, then the psychological scale always contains many items, the response of the subject is not classified as true or false answers. This psychological scale is used to express psychological aspects regarding self confidence [11].

This research design subject will be treated with two measurements, before and after group guidance services. The pretest and posttest before being given treatment after being given treatment, so the results of the treatment can be determined more accurately because it can be compared with the situation before being given treatment. Subjects in this study consisted of 7 students who have low selfconfidence. This study uses data analysis techniques by Wilcoxon Match Pair Test is to find differences in the mean pretest and posttest so researchers can see the difference in value between pretest and posttest.

\section{RESULT AND DISCUSSION}

Result

The study was conducted in class VIII as many as 149 students. Prior to the implementation of group guidance service, the author first perform data collection using a scale of self confidence. There are 7 students who score low to moderate, can be viewed categories self confidence predetermined researcher in table 1.

Table 1. Criteria Self Confidence

\begin{tabular}{|c|c|}
\hline Interval & Category \\
\hline $112-151$ & High \\
\hline $71-111$ & Moderate \\
\hline $30-70$ & Low \\
\hline
\end{tabular}

This study examines the validity of the questionnaire items using the Aiken's V. Aiken's V formula to calculate the content-validity-coefficient based on expert judgment of 4 guidance and counseling expert on an item regarding the extent to which the item represents the measured construct. Assessment is done by giving a number between 1 (very not represent or totally irrelevant) to 4 (very represent or very relevant). This study uses data analysis techniques with the Wilcoxon test that is by looking for differences in the mean pretest and posttest. This research will test the pretest and posttest, so author can see the difference in value between pretest and posttest through the Wilcoxon test.

Based on the results giving students self confidence scale data obtained are shown in table 2.

Table 2. Self Confidence Scale

\begin{tabular}{|c|c|c|c|}
\hline No. & Name & Score & Criteria \\
\hline 1 & ARB & 70 & Low \\
\hline 2 & GPA & 69 & Low \\
\hline 3 & GSM & 69 & Low \\
\hline 4 & HSA & 66 & Low \\
\hline 5 & IMA & 68 & Low \\
\hline 6 & MIK & 66 & Low \\
\hline 7 & MRA & 67 & Low \\
\hline
\end{tabular}

This research collection is using a scale of self confidence and also using interviews and observations acquired condition in which the seven subjects acquired behaviors that indicate a low self confidence. 


\section{Discussion}

Data obtained to determine the pretest and posttest results obtained from the charging scale confidence. Pretest is the result of scores obtained before the author organizes group guidance. After the implementation of the pretest, students who earn a low confidence score is given treatment group guidance service.

This criterion is based on the deployment of scale gained self confidence and is used to determine the subject of research and set confidence before and after group guidance service. The resulting increase confidence score can be seen in the following table:

Table 3. The Result Enhancement Self Confidence Score

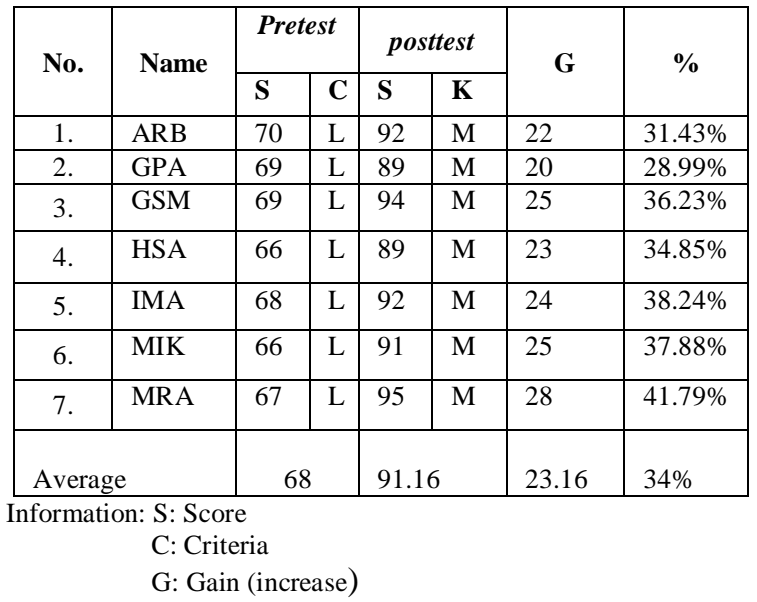

Based on the result of enhancement self confidence score in the form of quantitative conclusion that prior guidance given treatment group gained an average value of 68 in the category of low and after treatment guidance group posttest results increased to 91.16 into the category of being. There is a difference in value score of 23.16 between pretest and posttest. Then this shows that an increase in confidence after a given group guidance service in the amount of $34 \%$. This is a graph of enhancement self confidence students in learning :

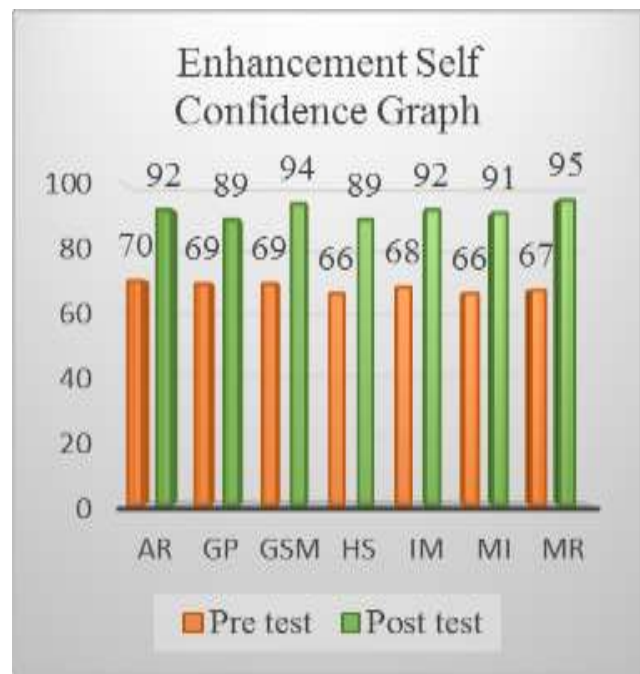

Fig. 1. Score comparison pretest and posttest self confidence
The treatment can be analyzed that the members are able to gain insight and understanding of the topics that have been discussed. The result that average showed a gradual behavioral changes that arise during the process of group guidance activities. Provision of group guidance service approach chosen so that the students are able to adapt and communicate well in a variety of situations.

Based on that averages have been shown for the gradual change in behavior that occurs during the process of the next group meeting. In other words, they have been able to apply the results of their understanding in a behavior that is raised during the process of group guidance activities at each subsequent meeting. So it is hoped that positive changes in behavior can always be applied in communication especially on group guidance activities.

The author provides group guidance service approach to enhance the self confidence in a low student self confidence in learning. Group guidance is a service that was held in the atmosphere of the group by leveraging group dynamics which covers the whole field of guidance [12]. Accordingly, group guidance can be interpreted as an attempt guidance is done through a situation, process and group activities. Guidance target groups are individuals in the group given individual guidance in order to get an understanding, selfacceptance, self-direction and self-realization in towards optimum development [13].

Students are directed to participate in group discussion activities, because group guidance is a means to support the optimal development of each student. The development of students who are secured in group guidance is communication and socialization skills. Communication and socialization skills are very important for students to have an active attitude and to be able to communicate and socialize well. The author provides a group guidance service approach in an effort to overcome low student self confidence in learning. Group guidance is a process of assistance to individuals by utilizing group dynamics. In addition, in group guidance services there are interactions among group members such as communication, belief, cooperation, and openness. However the task of the group leader is to prepare useful information to help the individual to achieve optimal development, prevent the emergence of a problem, be able to develop the potential that exists in him, make plans, make the right decisions, and to develop understanding of himself, others and the environment so that effective behavior is formed, both within the school environment and in the community, and more confident [14].

Group guidance in schools is a guidance service provided in a group setting, as well as information activities to a group of students to help them make appropriate plans and decisions [14]. Group guidance contains elements of group dynamics or group life. Intensive group dynamics, the discussion of topics in depth will encourage the development of feelings, thoughts, perceptions, insights, activeness and attitudes that support the realization of more effective behavior, students as group members interact with each other, expressing their opinions discussing topics in group guidance so that the activeness of students is needed in carrying out group guidance activities [15]. 
Improvement occurring in the different group members to one another. Group guidance service had a purpose as a medium of self-development to be able to practice speaking, capable of speech, learn to respect others, to control emotions, have a sense of responsibility and tolerance, can establish a good relationship with each other, and be able to accept and respect the opinions of others. A process of group guidance service is running properly and to achieve the objectives as stated above it is expected that each individual is able to maximize the potential that exists within him to be individuals who are more confident, especially in learning activities at school. In conclusion, the activities of group guidance service aims to provide the greatest possible extent both in terms of the understanding of the individual participants of group guidance as well as the participants who follow the guidance of the group, so they can make appropriate plans and decisions appropriate on matters pertaining to the problem facing either issue an individual or a group problem.

The function of group guidance service is an assortment like an individual counseling. In group guidance the members or group guidance participants have the same rights and opportunities both in expressing opinions or expressing criticism, which is meant here group guidance participants must not win alone or knock each other down, misunderstandings occur, and damage the personalities of each group member. Accordingly, group guidance is guidance and counseling services that enable a number of participants (counselees) together through group dynamics obtain some materials from sources of certain (mainly from the supervising teacher or counselor) useful support everyday life better individuals as subjects [15].

This is one of the causes of the increase in each group member to be different from one another, it is also caused by the dynamics of the group. Group dynamics require a student to be assertive, decisive in answering questions, assertive in giving conclusions or the other. So that students who initially are not strict become assertive. Students who can assertive means they have high self-confidence because they feels confident about what they do.

One of the traits that have high self confidence is able to neutralize the tensions that arise in various situations and being able to adapt and communicate well in a variety of situations [16]. While confidence is a condition in which individuals feel confident in the ability of its ring, and so he can solve the problem of knowing what is needed in his life, as well as how individuals are able to assess themselves and their environment [17]. Self-confidence is one of the aspects of personality such as belief in the ability of a person that is not influenced by others and may act according to whatever they want, happy, optimistic, tolerant, and responsible [18].

Self-confidence is one of the conditions that are essential for the individual to develop the activity and creativity in order to get achievement. However, self confidence does not grow by itself. To growing self confidence of the healthy interactions in the social environment of individuals and takes place continuously and sustainably. Self confidence does not just show up to individual, there are certain processes in individual so that there was the formation of self-confidence [19].
Self-confidence is an attitude or confidence in the ability of self, so that the actions are not too anxious, feel free to do things in accordance with the wishes and liable for his actions, polite in interacting with others, have the drive achievement and also known the advantages and disadvantages of self. Capability formation of self confidence is a process of learning how to respond to various stimuli from outside itself through interaction with its environment.

There are several aspects of confidence which is as follows: (1) The ability of self belief that a person's positive attitude about himself that he truly understood what he was doing; (2) Optimistic that a positive attitude person who always holds good in the face of everything about themselves, expectations and abilities; (3) The objective of self confident people is how to looking at problems or anything; (4) In accordance with the truth of things properly, not according to personal truth; (5) Responsible namely a person's willingness to bear everything that has been a consequence; and (6) Rational namely the analysis of a problem, something, something occurrences using accepted thinking by reason and in accordance with reality. Based on the foregoing it can be concluded aspects of self-confidence is as follows belief in the ability of self, optimistic, objective, responsible and rational [20].

It thus made clear that the confidence of students in the school can be built through different forms of activities, namely: to cultivate the courage to ask, coaching discussion, work on the problems in front of the class, as well as competing in the achievement of learning. Based on research by the authors approach in selected group guidance service so that students are able to adapt and communicate well in a variety of situations. The author provides group guidance service approach in tackling the confidence in a low student learning.

Group guidance service is a process aid to individuals by leveraging group dynamics. In addition, the group guidance service there is an interaction between group members, among others such as communication, trust, cooperation, and openness. One important role in the group guidance is the group leader. The task of the leader of the group was to prepare the information useful in order to help individuals to achieve optimal development, prevents the emergence of a problem, to develop the potential in him, to plan, to make the right decisions, and to develop an understanding of themselves, others and the surrounding environment so that the formation of effective behavior, both within the school and in the community, and more confident.

Group guidance service provided in the atmosphere of the group, as well as information activities to a group of students to help them plan and the right decision. Group guidance service was also held to provide information that is personal, vocational, and social means the provision of information in the form of measures intended to assist students in overcoming its problems, especially in school [21].

Based on the calculation of the confidence scale that has been filled out by students, the results show that the seven students have increased confidence by comparing the results of the pretest (before being given group guidance services) 
and posttest (after being given group guidance services). This is evident from the results of data analysis with using Wilcoxon test, where the zhitung $=-2,371$ is obtained. This price is then compared with ztable $=1,645$. Testing conditions if Zcount < Ztable maka Ho is rejected and $\mathrm{Ha}$ is accepted. It turns out that Zcount $=-2,371<$ Ztable $=1,645$ then Ho is rejected and Ha is accepted.

The conclusion from the above statement can be said that the group guidance service can not only help members of the group in increasing motivation to learn, but also can help the group members changed their attitude. It can be seen from the change in the attitude of members of the group are: 1) The members of the group who had been indifferent already started not, 2) members of the group tend to be quiet already started actively in the activities, 3) members of the group had dared to express his opinion, 4) members of the group start issued an opinion that can be understood by members of the group. Group guidance service is a purposeful activity, where in addition there are stages, there are the techniques that can be done so that the activities of group guidance can do better.

\section{CONCLUSION}

Self confidence can be enhanced through group guidance service. Based on the results of research and discussion, the conclusion that confidence can be enhanced through group guidance service. This can be seen from the comparison between pretest and posttest were increased with the average value of the difference between the value score of 23.16 or $34 \%$. Given group guidance service proven to be effective to enhance the self confidence of students. Improvement occurring in the different group members to one another. Group guidance service had a purpose as a medium of selfdevelopment to be able to practice speaking, able to issue an opinion to learn to respect other people, responsible, able to control their emotions, have tolerance, good relationships and be able to accept and respect the opinions of others. Group guidance service is one of the services that can provide opportunities for members to accept, express an opinion, and support each other. Group guidance services also help students to learn about themselves and others, as well as try or express new ideas. In addition, group guidance services help create interaction between members and leadership of the group. This interaction creates openness, enthusiasm for the better, and provides opportunities for students to give and receive opinions. Following group guidance services, adolescents who have lack self confidence will get a conducive and natural environment in accordance with the development phase and the opportunity to practice expressing ideas, opinions, ideas, and gaining new insights that can shape confident behavior [22]. A process of group guidance that goes well and can achieve the objectives as stated above it is expected that each individual is able to maximize the potential that exists within him to be individuals who are more confident, especially in learning activities at school. It is one that causes an increase in group members are different from each other. The increase that occurs in group members is different from each other. Group guidance services have a goal as a medium for self-development to be able to practice speaking, able to express opinions, learn to respect others, be able to control emotions, have a sense of responsibility and tolerance, can establish good relationships with each other, and are able to accept and respect people's opinions other. A process of group guidance services that runs well and can achieve the goals as mentioned above, it is expected that each individual is able to maximize the potential that exists in him to become more confident individuals, especially in learning activities at school. Based on the results of research in improving students' self confidence through group guidance service can be concluded that the self-confidence of students before getting into the group guidance including low criteria. Having given group guidance service increased to moderate, it was shown from the results there is a difference between pretest and posttest significant value that is 23.16 if percentage is $34 \%$.

\section{ACKNOWLEDGMENT}

The author deeply indebted to my lecturers and friends for support, inspiration and guidance toward the writing of this article.

\section{REFERENCES}

[1] Hakim, T. (2002). Mengatasi Rasa Tidak Percaya Diri. Jakarta: Puspa Swara, p 5.

[2] Iswidharmanjaya, Derry. (2013). Satu Hari Menjadi Lebih Percaya Diri. Jakarta: Media Komputido.

[3] Widjaja, H. (2016). Berani Tampil Beda dan Percaya Diri (Tutorial Lengkap Tampil Beda dan Percaya Diri di Segala Siuasi). Yogyakarta: Araska.

[4] Mastur, Sugiharto, D.Y.P \& Sukiman. (2012). Konseling kelompok dengan teknik restrukturisasi kognitif untuk meningkatkan kepercayaan diri siswa. Jurnal Fakultas Psikologi. 3(1), pp 9-15.

[5] Jannah, Izzatul. (2006). Pengembangan Diri Remaja: Every Day is Pede Day. Solo: Era Eureka.

[6] Romlah, T. (2006). Teori dan Praktek Bimbingan Kelompok. Malang : Universitas Negeri Malang.

[7] Siradj, Sjahudi. (2012). Pengantar Bimbingan dan Konseling. Surabaya : PT. Revka Media.

[8] John W. Santrock (2007). Psikologi Pendidikan. Jakarta: Kencana.

[9] Sugiyono. (2014). Metode Penelitian Pendidikan Pendekatan Kuantitatif, Kualitatif dan R\&D. Bandung: Alfabeta.

[10]Azwar, S. (2010). Penyusunan Skala Psikologi. Yogyakarta: Pustaka Pelajar.

[11]Amti, Erman dan Prayitno. (2008). Layanan Bimbingan Dan Konseling Kelompok. Padang: Jurusan Bimbingan dan Konseling FIP Universitas Negeri Padang

[12] Sedanayasa, Gede dkk. (2010). Dasar-Dasar Bimbingan Konseling. Singaraja: Jurusan Bimbingan Konseling.

[13]Mugiarso, Heru, dkk. 2004. Bimbingan Dan Konseling. Semarang: UPT MKDK UNNES.

[14] Sukardi, Dewa Ketut dkk. (2008). Proses Bimbingan dan konseling di Sekolah. Jakarta: Rineka Cipta. hlm.78.

[15]Hakim, T, (2002). Mengatasi Rasa Tidak Percaya Diri. Jakarta: Puspa Swara, p 5.

[16]Surya, H. (2007). Percaya Diri Itu Penting. Elex Media Komputindo.

[17] Ghufron dan Risnawati. (2010). Teori-teori Psikologi. Yogyakarta: ArRuzz Media Group.

[18]Hakim, T, (2002). Mengatasi Rasa Tidak Percaya Diri. Jakarta: Puspa Swara, p 145 .

[19]Lauster, P. (2003). Tes Kepribadian (alih bahasa: D.H. Gulo). Jakarta: PT. Bumi Aksara.

[20]Prayitno. (2004). Layanan Bimbingan Kelompok Dan Konseling Kelompok. Padang: Universitas Negeri Padang. hlm 309.

[21]Romlah, T. (2006). Teori dan Praktek Bimbingan Kelompok. Malang : Universitas Negeri Malang, p 86.

[22]Nengsih, Firman, \& Mega. (2015). Pengaruh layanan bimbingan kelompok terhadap perencanaan arah karier siswa SMA pembangunan laboratorium. Universitas Negeri Padang, pp 136-146. 